\title{
Polymorphism and Discrimination Capacity of Randomly Amplified Polymorphic Markers in an Olive Germplasm Bank
}

\author{
A. Belaj, ${ }^{1}$ I. Trujillo, R. de la Rosa, and L. Rallo \\ Departamento de Agronomía, Universidad de Cordoba, Apdo, 3.048, 14080. Cordoba, Spain \\ M.J. Giménez \\ Instituto de Agricultura Sostenible, CSIC, Apdo, 4.084. 14080, Cordoba, Spain
}

AdDitional INDEX words. Olea europaea, cultivar identification, RAPD, PAGE, AGE, electrophoresis

\begin{abstract}
Random amplified polymorphic DNA (RAPD) analysis was performed on the main Mediterranean cultivars of olive (Olea europaea L.) from the Germplasm Bank of the Centro de Investigación y Formación Agraria "Alameda del Obispo" in Cordoba, Spain. One hundred and ninety reproducible amplification fragments were identified using 46 random primers followed by agarose gel electrophoresis. Some $63.2 \%$ of the amplification products were polymorphic, with an average of 2.6 RAPD markers obtained for each primer. The combination of polymorphic markers resulted in 244 banding patterns. The high degree of polymorphism detected made identification of all the cultivars (51) possible by combining the RAPD banding patterns of just only four primers: OPA-01, OPK-08, OPX-01, and OPX-03. Cultivarspecific RAPD markers and banding patterns were also found. A dendrogram based on unweighted pair-group method cluster analysis was constructed using a similarity matrix derived from the RAPD amplification products generated by the 46 primers. Three major groups of cultivars could be distinguished by RAPD analysis: 1) cultivars from east and northeast Spain, 2) Turkish, Syrian, and Tunisian cultivars, and 3) the majority of common olive cultivars in Spain. The dendrogram thus showed a good correlation between the banding patterns of olive cultivars and their geographic origin. A higher level of polymorphism was observed when polyacrylamide gel electrophoresis was used to separate the amplification products. Thus, adequate use of RAPD technology offers a valuable tool to distinguish between olive cultivars.
\end{abstract}

Olive (Olea europaea L.) is among the oldest of Mediterranean fruit crops. Many different genotypes are currently cultivated throughout the warm temperate regions of the world. Bartolini et al. (1998) lists 1200 cultivars with more than 3000 different common names in germplasm collections located in 24 countries. This diversity is due to local selection of outstanding genotypes and subsequent cloning. Names of cultivars refer mainly to some morphological traits, particularly of the fruit, or their supposed location of origin or their practical utility (Barranco and Rallo, 1984). This leads to the presence of a high number of homonyms and synonyms in olive. The diversity of cultivars and the confusion in naming require precise methods of discrimination for cultivar identification and classification.

Classical approaches for identifying olive cultivars are based on morphology (Barranco and Rallo 1984; Cimato et al., 1993; Leitão, 1988; Prevost et al., 1993; Tous and Romero, 1993). Although these markers provide a very useful tool for identification, they have limitations because of environmental influences, and the need for extensive observations of mature plants.

Recently, enzyme markers have provided an alternative means of olive cultivar identification due mainly to the high level of polymorphism found in this species. Most of these studies have been conducted using pollen extracts (Pontikis et al., 1980;

Received for publication 7 Feb. 2000. Accepted for publication 11 July 2000. Contribution from the Department of Agronomy, University of Cordoba, Cordoba, Spain. This study was supported partially by a grant provided by the International Centre for Advanced Mediterranean Agronomic Studies (CIHEAM), Zaragoza, Spain and by an European Union project (FAIR-CT95-0689). We would like to thank J. I. Hormaza, A. Martín, G. Dorado, K. Tobutt, and M. Herrero for critical reading of the manuscript and valuable advice. The data of this study were used as part of a MS Thesis of A. Belaj. The cost of publishing this paper was defrayed in part by the payment of page charges. Under postal regulations, this paper therefore must be hereby marked advertisement solely to indicate this fact.

${ }^{1}$ To whom reprint requests should be addressed.
Trujillo et al., 1995). However, use of pollen limits sample collection to mature trees at the time of flowering. Ouazzani et al. (1993) used successfully leaf allozymes to study genetic variation in cultivated and wild olives. However enzyme systems of leaves showed a lower level of polymorphism than pollen allozymes and protein extraction was more laborious (Patumi et al., 1994).

Randomly amplified polymorphic DNA (RAPD) markers (Welsh and McClelland 1990; Williams et al., 1990) are independent of environmental conditions, exhibit a high degree of polymorphism and provide a quick and simple methodology for analysis of plant material at any stage of development. However, RAPD markers also have limitations such as their dominant character (Williams et al., 1990). Reliability may be increased by replicate analyses, involving independently isolated DNA samples and performed at different times. Caution regarding data analysis (band selection and scoring), seems to be critical for maintaining a high level of accuracy (Gogorcena and Parfitt, 1994; Weeden et al., 1992; Williams et al., 1991).

RAPD analysis with agarose gel electrophoresis (AGE) has been used successfully for cultivar identification and biodiversity studies of different fruit tree species such as apple (Malus) (Landry et al., 1994), peach (Prunus persica L. Batch) (Lu et al., 1996, Warburton and Bliss, 1996), cherry (Prunus avium L.) (Gerlach and Stosser, 1997), pistachio (Pistacia vera L.) (Hormaza et al., 1994; 1998), walnut (Juglans regia L.) (Nicese et al., 1998), almond (Prunus amygdalus Batsch) (Bartolozzi et al., 1998), plum (Prunus domestica L.) (Ortiz et al., 1997), lemon [Citrus lemon (L.) Burm. f. and mandarins, Citrus deliciosa Tenore] (Deng et al., 1995, Machado et al., 1996), mango (Mangifera indica L.) (Lopez-Valenzuela et al., 1997) and chestnut (Castanea sativa Mill.) (Galderisi et al., 1998).

In olive, RAPD-AGE analysis, conducted on a limited number of cultivars, has proven useful for identification and classifi- 
cation studies (Bogani et al., 1994; Fabbri et al., 1995; Vergari et al., 1996; Wiesman et al., 1998). Increasingly polyacrylamide gel electrophoresis (PAGE) is being used for resolving DNA fragments in identification studies of other species (Bassam et al., 1991a; Caetano-Anollés and Bassam, 1997; Caetano-Anollés et al., 1991; Filippis et al., 1996; Harada et al., 1993; Ronning et al., 1995).

A germplasm bank that currently includes 329 cultivars ob-

Table 1. Olive cultivars analyzed, including their registration number $(\mathrm{RN})$ in the collection, the countries of origin, and the banding patterns obtained with the primers OPA-01, OPK-08, OPX-01, and OPX-03 in agarose.

\begin{tabular}{|c|c|c|c|c|c|c|}
\hline Cultivars & $\mathrm{RN}$ & Origin & OPA-01 & OPK-08 & OPX-01 & OPX-03 \\
\hline Alfafara & 605 & Spain & $\mathrm{A}^{\mathrm{Z}}$ & $\mathrm{H}$ & $\mathrm{E}$ & $\mathrm{H}$ \\
\hline Aloreña & 829 & Spain & $--{ }^{y}$ & I & $\mathrm{E}$ & B \\
\hline Arbequina & 231 & Spain & $\mathrm{H}$ & $\mathrm{E}$ & $\mathrm{G}$ & $\mathrm{H}$ \\
\hline Ascolana Tenera & 62 & Italy & A & $\mathrm{J}$ & $\mathrm{K}$ & $\mathrm{B}$ \\
\hline Ayvalik & 97 & Turkey & $\mathrm{D}$ & $\mathrm{E}$ & $\mathrm{G}$ & $\mathrm{J}$ \\
\hline Bical & 387 & Spain & A & $\mathrm{C}$ & $\mathrm{E}$ & $\mathrm{H}$ \\
\hline Blanqueta & 11 & Spain & $\mathrm{G}$ & $\mathrm{E}$ & B & $\mathrm{L}$ \\
\hline Çakir & 96 & Turkey & $\mathrm{D}$ & $\mathrm{I}$ & $\mathrm{G}$ & $\mathrm{F}$ \\
\hline Carolea & 736 & Italy & $\mathrm{C}$ & $\mathrm{H}$ & $\mathrm{G}$ & B \\
\hline Castellana & 576 & Spain & $\mathrm{F}$ & $\mathrm{D}$ & $\mathrm{J}$ & $\mathrm{H}$ \\
\hline Changlot Real & 15 & Spain & $\mathrm{F}$ & $\mathrm{E}$ & $\mathrm{J}$ & $\mathrm{F}$ \\
\hline Chemlali & 744 & Tunisia & $\mathrm{B}$ & $\mathrm{E}$ & B & I \\
\hline Chetoui & 113 & Tunisia & $\mathrm{D}$ & $\mathrm{F}$ & B & I \\
\hline Cobrançosa & 124 & Portugal & A & $\mathrm{J}$ & $\mathrm{J}$ & $\mathrm{H}$ \\
\hline Coratina & 79 & Italy & $\mathrm{E}$ & $\mathrm{E}$ & $\mathrm{E}$ & $\mathrm{I}$ \\
\hline Cordovil de Serpa & 131 & Portugal & $\mathrm{G}$ & I & $\mathrm{G}$ & $\mathrm{F}$ \\
\hline Cornicabra & 10 & Spain & A & $\mathrm{G}$ & $\mathrm{K}$ & $\mathrm{H}$ \\
\hline Domat & 94 & Turkey & $\mathrm{G}$ & $\mathrm{E}$ & B & $\mathrm{G}$ \\
\hline Empeltre & 13 & Spain & $\mathrm{G}$ & $\mathrm{E}$ & $\mathrm{H}$ & $\mathrm{E}$ \\
\hline Farga & 12 & Spain & $\mathrm{A}$ & $\mathrm{E}$ & I & $\mathrm{C}$ \\
\hline Frantoio & 80 & Italy & $\mathrm{G}$ & I & $\mathrm{F}$ & $\mathrm{I}$ \\
\hline Galega & 128 & Portugal & $\mathrm{C}$ & $\mathrm{J}$ & $\mathrm{K}$ & $\mathrm{H}$ \\
\hline Gemlik & 92 & Turkey & A & B & $\mathrm{Z}$ & $\mathrm{H}$ \\
\hline Gerboui & 538 & Tunisia & $\mathrm{G}$ & $\mathrm{E}$ & B & $\mathrm{F}$ \\
\hline Gordal Sevillana & 234 & Spain & $\mathrm{F}$ & $\mathrm{E}$ & $\mathrm{K}$ & A \\
\hline Hojiblanca & 2 & Spain & $\mathrm{C}$ & $\mathrm{G}$ & $\mathrm{J}$ & $\mathrm{H}$ \\
\hline Kaissy & 140 & Syria & $\mathrm{F}$ & $\mathrm{B}$ & $\mathrm{G}$ & A \\
\hline Kalamon & 105 & Greece & $\mathrm{F}$ & $\mathrm{E}$ & $\mathrm{B}$ & $\mathrm{J}$ \\
\hline Konservolia & 219 & Greece & $\mathrm{D}$ & $\mathrm{E}$ & B & $\mathrm{G}$ \\
\hline Koroneiki & 218 & Greece & $\mathrm{B}$ & $\mathrm{G}$ & $\mathrm{B}$ & $\mathrm{D}$ \\
\hline Leccino & 82 & Italy & $\mathrm{C}$ & $\mathrm{E}$ & $\mathrm{J}$ & $\mathrm{H}$ \\
\hline Lechín de Granada & 54 & Spain & A & $\mathrm{H}$ & $\mathrm{H}$ & $\mathrm{H}$ \\
\hline Lechín de Sevilla & 5 & Spain & $\mathrm{F}$ & A & $\mathrm{E}$ & $\mathrm{I}$ \\
\hline Manzanilla Cacereña & 430 & Spain & $\mathrm{F}$ & I & $\mathrm{K}$ & $\mathrm{H}$ \\
\hline Manzanilla Sevillana & 21 & Spain & $\mathrm{F}$ & $\mathrm{L}$ & $\mathrm{J}$ & $\mathrm{H}$ \\
\hline Memecik & 93 & Turkey & $\mathrm{D}$ & $\mathrm{E}$ & $\mathrm{B}$ & $\mathrm{F}$ \\
\hline Meski & 115 & Tunisia & $\mathrm{D}$ & $\mathrm{I}$ & $\mathrm{G}$ & $\mathrm{B}$ \\
\hline Moraiolo & 78 & Italy & $\mathrm{D}$ & I & $\mathrm{H}$ & $\mathrm{I}$ \\
\hline Morisca & 17 & Spain & A & $\mathrm{J}$ & $\mathrm{B}$ & $\mathrm{H}$ \\
\hline Morrut & 224 & Spain & A & $\mathrm{L}$ & $\mathrm{J}$ & $\mathrm{E}$ \\
\hline Picholine Marocaine & 101 & Morocco & A & $\mathrm{J}$ & $\mathrm{K}$ & $\mathrm{H}$ \\
\hline Picual & 9 & Spain & $\mathrm{F}$ & $\mathrm{H}$ & $\mathrm{J}$ & $\mathrm{H}$ \\
\hline Picudo & 3 & Spain & --- & K & $\mathbf{J}$ & $\mathrm{H}$ \\
\hline Sevillenca & 227 & Spain & $\mathrm{F}$ & $\mathrm{K}$ & $\mathrm{B}$ & $\mathrm{B}$ \\
\hline Sourani & & Syria & --- & $\mathrm{I}$ & G & $\mathrm{B}$ \\
\hline Uslu & 95 & Turkey & $\mathrm{B}$ & I & A & B \\
\hline Verdial de Badajoz & 988 & Spain & --- & $\mathrm{H}$ & $\mathrm{K}$ & $\mathrm{H}$ \\
\hline Verdial de Huevar & 6 & Spain & $\mathrm{F}$ & $\mathrm{E}$ & $\mathrm{K}$ & $\mathrm{H}$ \\
\hline Verdial de Velez-Málaga & 883 & Spain & -- & $\mathrm{G}$ & $\mathrm{L}$ & $\mathrm{H}$ \\
\hline Villalonga & 364 & Spain & $\mathrm{E}$ & I & $\mathrm{J}$ & $\mathrm{B}$ \\
\hline Zaity & 788 & Syria & $\mathrm{E}$ & $\mathrm{D}$ & $\mathrm{D}$ & A \\
\hline
\end{tabular}

${ }^{\mathrm{z}}$ Letters represent the banding patterns for each primer.

${ }^{\mathrm{y}}$ Missing data. 
tained from 16 Mediterranean countries was established in the CIFA, Alameda del Obispo, Cordoba, Spain, in 1970. This collection now represents one of the largest olive collections in the world (del Río and Caballero, 1994). Furthermore, the number of accessions maintained in this germplasm bank is increasing due to a current EU project (RESGEN CT, 96/97) aimed at collecting new genetic resources from 11 Mediterranean countries. Consequently, an easy and reliable method is required to characterize this large and diverse collection of genotypes. Therefore, the objective of this study was to assess the capacity of RAPD markers to discriminate and classify olive cultivars in various germplasm banks. The capacity of two separation matrices (AGE and PAGE) to detect polymorphism in olive and hence to discriminate between cultivars was also compared.

\section{Material and Methods}

Plant material. For RAPD-AGE 51 cultivars of olive, constituting a representative sample of the genetic diversity found in the germplasm bank of the CIFA Alameda del Obispo in Córdoba, Spain, were used (Table 1). These cultivars were chosen on the basis of their different geographic origins and economic importance within the Mediterranean region. All of the cultivars had been described previously and identified by stan- dard morphological descriptions (Barranco and Rallo, 1984). Among them, homonyms such as 'Lechín de Sevilla' and 'Lechín de Granada'; 'Manzanilla de Sevilla' and 'Manzanilla Cacereña'; 'Verdial de Badajoz', 'Verdial de Vélez-Málaga', and 'Verdial de Huevar' were also included. For RAPD-PAGE only 46 of the 51 cultivars were used because DNA of 'Aloreña', 'Sourani', 'Verdial de Badajoz', 'Verdial de Velez-Málaga', and 'Picudo' was not available.

DNa EXTRACTION. Genomic DNA was extracted from young leaf tissue collected in Spring 1997, following the method of Murray and Thompson (1980) with modifications, in particular an increase in the concentration of sodium bisulphite from $20 \mathrm{~mm}$ to $40 \mathrm{~mm}$. DNA was extracted three times for each cultivar. Estimation of DNA concentration and quality was based on the visual method of Sambrook et al. (1989) in which DNA samples, separated by $0.8 \%$ AGE in TBE buffer (100 mM Tris-HCl, $89 \mathrm{~mm}$ boric acid, $1 \mathrm{~mm} \mathrm{Na} \mathrm{N}_{2}$ EDTA, pH 8.3), were stained with ethidium bromide $\left(0.5 \mu \mathrm{g} \cdot \mathrm{mL}^{-1}\right)$ and band intensities were compared to lambda DNA standards $\left(50,100,200\right.$, and $\left.300 \mathrm{ng} \cdot \mu \mathrm{L}^{-1}\right)$.

Polymerase chain Reaction. Ninety five decamer oligonucleotides from kits A, C, D, E, K, Q, R, S, X, and Z (Operon Technologies, Alameda, Calif.) were screened by PCR amplification on agarose. Comparison of band resolution on polyacrylamide and agarose was performed with four primers from the kits
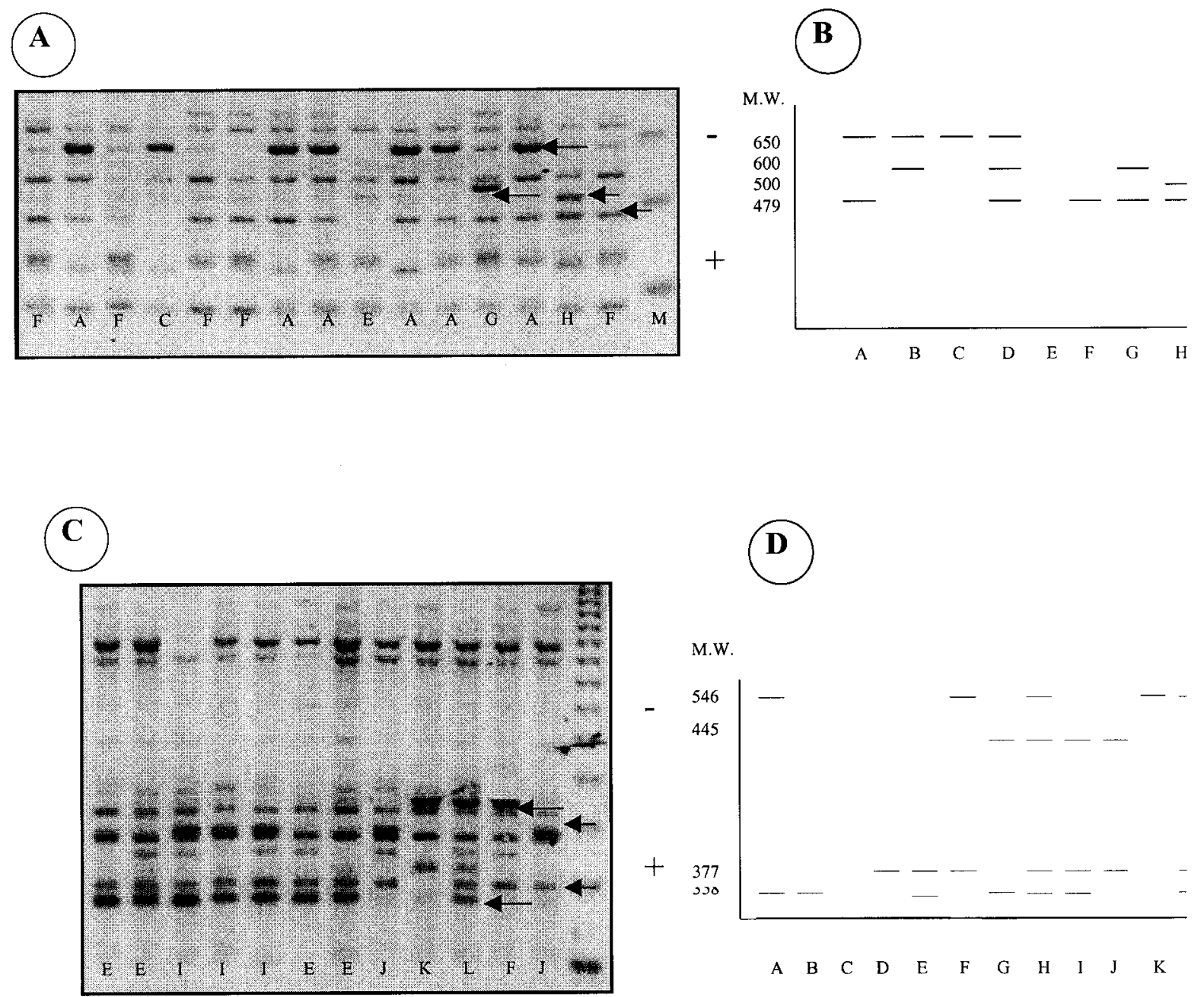

Fig. 1. RAPD amplification products and schematic representation of the banding patterns obtained with the primers (A and B) OPA-01 and (C and D) OPK-08 under AGE. The selected amplification fragments are indicated with arrows. The letters at the bottom of the photographs correspond to the banding patterns. The lane at the right end of the gel corresponds to the molecular marker (M). In the representation of banding patterns, the molecular weight (M.W.) is indicated on the Y-axis. 
$\mathrm{E}, \mathrm{X}$, and Z. DNA was amplified in $20 \mu \mathrm{L}$ reaction mixtures containing 20-40 ng of template DNA, 0.05 U AmpliTaq DNA polymerase Stoffel fragment (PE Biosystem, Foster City, Calif.), $0.75 \mathrm{~mm}$ each of dNTP (Roche, Basel, Switzerland), $20 \mu \mathrm{m}$ of the primer, $25 \mathrm{~mm} \mathrm{MgCl}_{2}, 50 \mathrm{~mm} \mathrm{KCl}$ and $10 \mathrm{~mm}$ Tris-HCl, (pH 8.3). The reactions were performed in a thermal cycler (PE Biosystem, GeneAmp PCR System 9600, Norwalk, Conn.) programmed for 1 cycle of $1 \mathrm{~min}$ at $94{ }^{\circ} \mathrm{C}$ followed by 40 cycles of $20 \mathrm{~s}$ at $94{ }^{\circ} \mathrm{C}$, $20 \mathrm{~s}$ at $35^{\circ} \mathrm{C}$ and $2 \mathrm{~min}$ at $72{ }^{\circ} \mathrm{C}$, for denaturing, primer annealing, and extension, respectively. The last cycle was followed by incubation for $6 \mathrm{~min}$ at $72{ }^{\circ} \mathrm{C}$. All the reactions were conducted three times using DNA of different extractions and different lots of the AmpliTaq DNA polymerase.

SEPARATION AND VISUALIZATION OF THE AMPLIFICATION PRODuCTs. Agarose gels (AGE) (Seakem, Nusieve, FMC, Rockland, Maine) of $25 \times 15 \mathrm{~cm}(2 \% \mathrm{w} / \mathrm{v})$ were prepared and run in TBE, pH 8.3, (100 mm Tris-HCl, 89 mm boric acid, and $1 \mathrm{~mm} \mathrm{Na}_{2}$ EDTA) buffer at $120 \mathrm{~V}$ for $3.3 \mathrm{~h}$ stained with ethidium bromide $(0.5$ $\mathrm{mg} \cdot \mathrm{mL}^{-1}$ ) and photographed under ultraviolet (UV) light using a DC 120 Digital Camera (Kodak, Rochester, N.Y.).

Polyacrylamide gels (PAGE) of $18 \times 16 \mathrm{~cm}$ containing $10 \%$ acrylamide, $0.126 \%$ piperazine diacrylamide crosslinker in 0.375 м Tris- $\mathrm{HCl}, \mathrm{pH} 8.8$, were separated in Tris glycine $(0.025$ м Tris, and $0.192 \mathrm{~m}$ glycine) at $30 \mathrm{~mA}$ per gel for $3.5 \mathrm{~h}$. The DNA was visualized by silver staining as described by Bassam et al., (1991b). Gels were photographed using a digital camera as
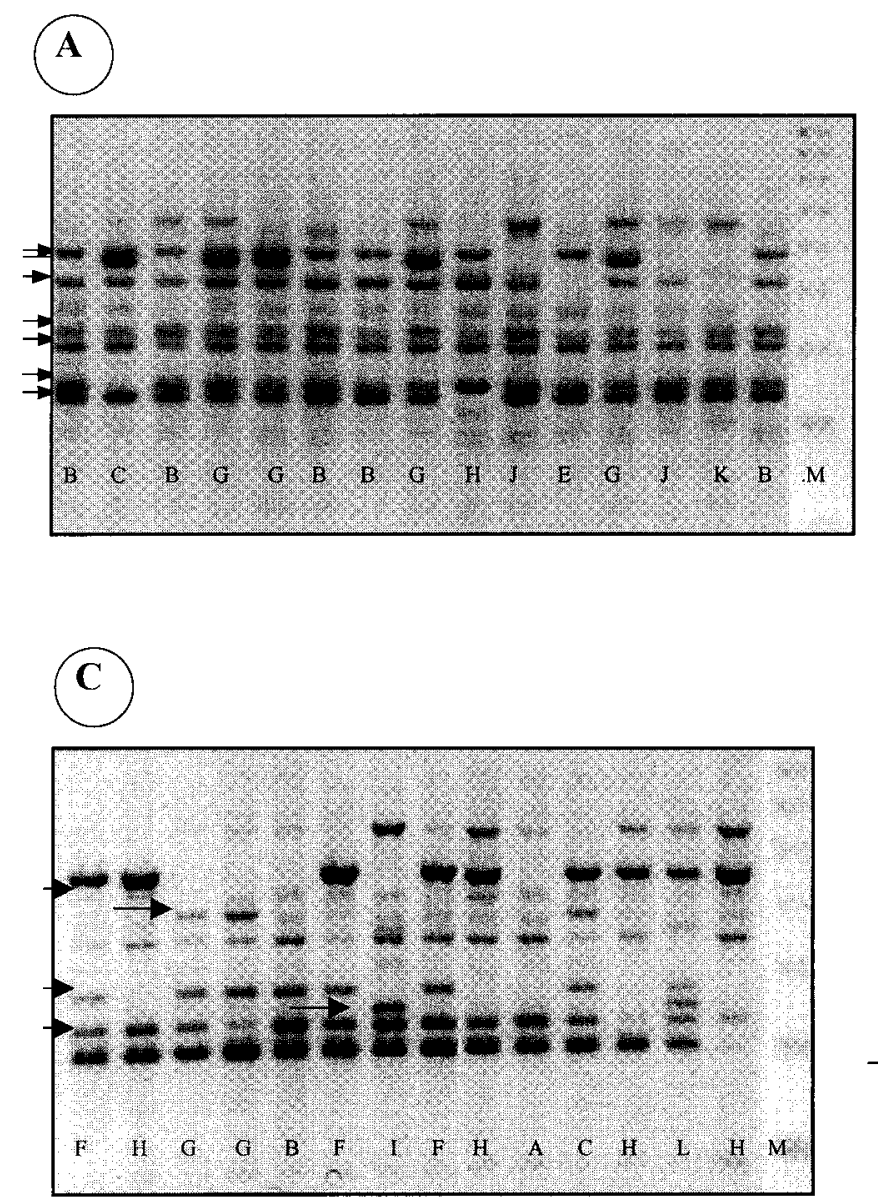

described previously. Molecular sizes of the amplification products were estimated using a 123-base pair (bp) DNA ladder (Sigma Chem. Co. St. Louis, Mo.).

DATA ANALYSIS. For gel analyses and accurate visualization of the bands, Whole Band Analyzer (Biomage, Ann Arbor, Mich.) was used. Whole Band Matcher from the same manufacturer was used for computing band sizes and for automated data output. RAPD bands were scored as 1 (present) or 0 (absent) in a binary matrix for each primer. A conservative criterion for the selection of bands was used. Only reproducible and well-defined bands were considered as potential polymorphic markers. The amplification banding patterns of two cultivars ('Arbequina' and 'Lechín de Sevilla') and bulked DNA were used as standards for comparing different gels. Banding patterns, i.e., the different combinations of bands obtained for each primer, were designated by the name of the respective primer followed by a capital letter (Figs. 1 and 2). The level of polymorphism of the primer (polymorphic bands per total bands), relative frequency of polymorphic bands (cultivars where a polymorphic bands $=$ present/total number of cultivars) were calculated. Relative frequency of banding patterns (number of cultivars with the same banding pattern/total number of cultivars) were also calculated.

Jaccard's (1908) coefficient of similarity was calculated, and the cultivars were grouped by cluster analysis using the unweighted pair-group method (UPGMA). The computer program used was SYSTAT Version 7.0/1977 from SPSS, Inc., Chicago, Ill.
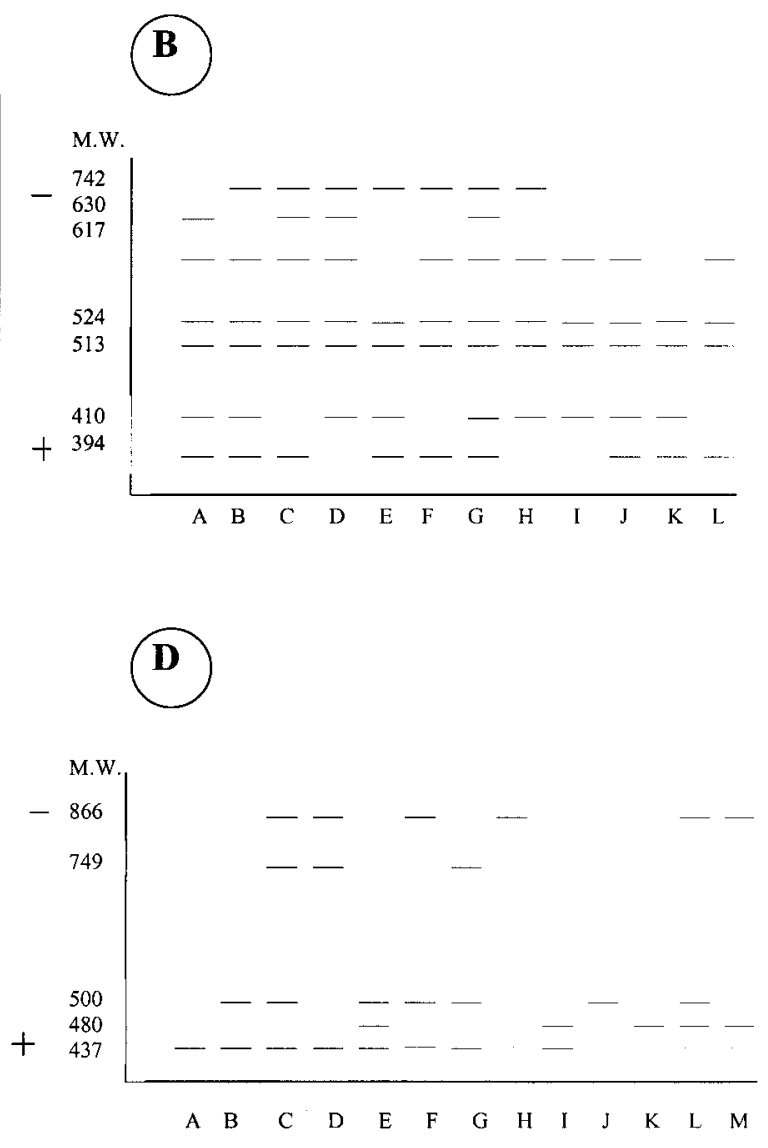

Fig. 2. RAPD amplification products and schematic representation of the banding patterns obtained with the primers (A and $\mathbf{B})$ and $(\mathbf{C}$ and $\mathbf{D})$ OPX-01 and OPX-03 under AGE. The selected amplification fragments are indicated with arrows. The letters at the bottom of the photographs correspond to the banding patterns. The first lane at the right end of the gel corresponds to the molecular marker (M). In the representation of banding pattern, the molecular weight (M.W.) is indicated on the Y-axis. 
Table 2. Selected primers in agarose gel electrophoresis, their polymorphism $(\mathrm{P})$ to the total number of bands (T), and the number of banding patterns obtained.

\begin{tabular}{|c|c|c|c|c|c|}
\hline Primers & $\mathrm{P} / \mathrm{T}$ & Banding patterns & Primers & $\mathrm{P} / \mathrm{T}$ & Banding patterns \\
\hline$\overline{\mathrm{OPA}-01}$ & $4 / 4$ & 8 & OPK-19 & $2 / 5$ & 4 \\
\hline OPA-02 & $4 / 4$ & 8 & OPK-20 & $2 / 4$ & 3 \\
\hline OPA-05 & $2 / 3$ & 4 & OPQ-09 & $3 / 6$ & 8 \\
\hline OPA-10 & $2 / 5$ & 4 & OPQ-10 & $3 / 3$ & 5 \\
\hline OPC-09 & $2 / 6$ & 6 & OPQ-14 & $2 / 2$ & 4 \\
\hline OPC-11 & $3 / 5$ & 6 & OPQ-15 & $2 / 3$ & 4 \\
\hline OPC-15 & $1 / 3$ & 2 & OPQ-17 & $1 / 4$ & 2 \\
\hline OPD-01 & $3 / 3$ & 8 & OPR-01 & $2 / 4$ & 4 \\
\hline OPD-03 & $3 / 4$ & 7 & OPR-06 & $2 / 2$ & 3 \\
\hline OPD-05 & $4 / 5$ & 7 & OPR-07 & $2 / 3$ & 4 \\
\hline OPE-02 & $3 / 6$ & 6 & OPR-09 & $3 / 4$ & 5 \\
\hline OPE-07 & $3 / 4$ & 5 & OPR-13 & $3 / 4$ & 5 \\
\hline OPE-14 & $2 / 4$ & 3 & OPR-20 & $2 / 6$ & 3 \\
\hline OPE-20 & $1 / 3$ & 2 & OPS-03 & $3 / 4$ & 5 \\
\hline OPK-02 & $2 / 3$ & 3 & OPS-11 & $2 / 3$ & 3 \\
\hline OPK-04 & $3 / 7$ & 5 & OPS-14 & $1 / 3$ & 2 \\
\hline OPK-08 & $4 / 4$ & 12 & OPX-01 & $5 / 7$ & 12 \\
\hline OPK-11 & $2 / 4$ & 3 & OPX-03 & $5 / 5$ & 13 \\
\hline OPK-12 & $2 / 5$ & 4 & OPZ-07 & $2 / 3$ & 2 \\
\hline OPK-14 & $3 / 3$ & 5 & OPZ-11 & $5 / 6$ & 10 \\
\hline OPK-16 & $6 / 8$ & 15 & OPZ-12 & $2 / 2$ & 4 \\
\hline OPK-17 & $4 / 5$ & 10 & OPZ-18 & $1 / 4$ & 2 \\
\hline OPK-18 & $1 / 3$ & 2 & OPZ-19 & $1 / 2$ & 2 \\
\hline Total & $64 / 101$ & 135 & Total & $56 / 89$ & 109 \\
\hline
\end{tabular}

\section{Results}

STUdY OF RAPD-AGE VARIABILITY IN OLIVE. Forty-six decamer oligonucleotide primers were selected from the 95 screened (Table 2). Selection was based on the quality of the amplifications, level of polymorphism, and consistency of the pattern of amplification in the three replications.

A total of 120 polymorphisms ( 2.6 polymorphic markers per primer) out of 190 reproducible products (4.1 fragments per primer) were obtained from the 46 primers when resolved in AGE (Table 2). The molecular weight of the amplification products varied from 117-bp (OPZ-18) to 1242-bp (OPC-11). The number of bands per primer ranged from two (OPQ-14, OPR-06, OPZ-12, and OPZ-19) to eight (OPK-16), whereas the number of polymorphic bands per primer ranged from 1 to 6 , corresponding to $63.2 \%$ of the amplification products. High variability in the frequency of polymorphic bands in the cultivars studied was observed. This frequency varied from 0.02 (bands present in only one cultivar of

Table 3. Unique bands with their molecular weight (the criteria used to score them and the cultivars identified).

\begin{tabular}{lcc}
\hline \hline $\begin{array}{l}\text { Unique markers } \\
\text { (AGE) }\end{array}$ & $\begin{array}{c}\text { Identification } \\
\text { criteria }\end{array}$ & $\begin{array}{c}\text { Cultivar } \\
\text { identified }\end{array}$ \\
\hline OPD-05.869 & Presence & Frantoio \\
OPE-07.371 & Absence & Coratina \\
OPK-19.731 & Absence & Zaity \\
OPK-19.584 & Presence & Zaity \\
OPK-02.731 & Presence & Frantoio \\
OPK-20.506 & Presence & Uslu \\
OPQ-09.522 & Absence & Morisca \\
OPS-11.466 & Presence & Koroneiki \\
OPZ-11.583 & Presence & Farga \\
\hline
\end{tabular}

the 51 studied) to 0.96 (bands absent in only one cultivar of the 51 studied). In general, the average frequency of the above-mentioned bands was high (0.42).

Table 4. Cultivars identified by the use of unique markers for the indicated primers resolved in agarose.

\begin{tabular}{ll}
\hline \hline Cultivar & Primers \\
\hline Arbequina & OPA-01 \\
Ascolana Tenera & OPK-16, OPQ-09, OPC11 \\
Bical & OPK-08 \\
Blanqueta & OPK-16, OPX-03 \\
Chetoui & OPR-09, OPK-08 \\
Cobrançosa & OPA-05 \\
Coratina & OPE-07, OPC11 \\
Empeltre & OPZ11, OPQ-09 \\
Farga & OPS-03, OPX-01, OPX-03, OPZ.11 \\
Frantoio & OPD-05, OPX-01, OPC-11, OPK-02 \\
Gemlik & OPX-01 \\
Gerboui & OPR-09 \\
Koroneiki & OPQ-09, OPS-11, OPX-03 \\
Lechín de Granada & OPZ-11 \\
Lechín de Sevilla & OPD-05, OPK-08, OPK-16 \\
Moraiolo & OPX-03 \\
Morisca & OPQ-09 \\
Morrut & OPK-08 \\
Picholine Marocaine & OPA-02 \\
Sevillenca & OPK-17 \\
Sourani & OPC-09 \\
Uslu & OPK-16, OPK-20, OPX-01 \\
Verdial de Huevar & OPC-09 \\
Verdial de Vélez Malaga & OPK-17, OPX-01 \\
Zaity & OPK-19, OPK-17, OPX-01, OPK-16 \\
\hline
\end{tabular}




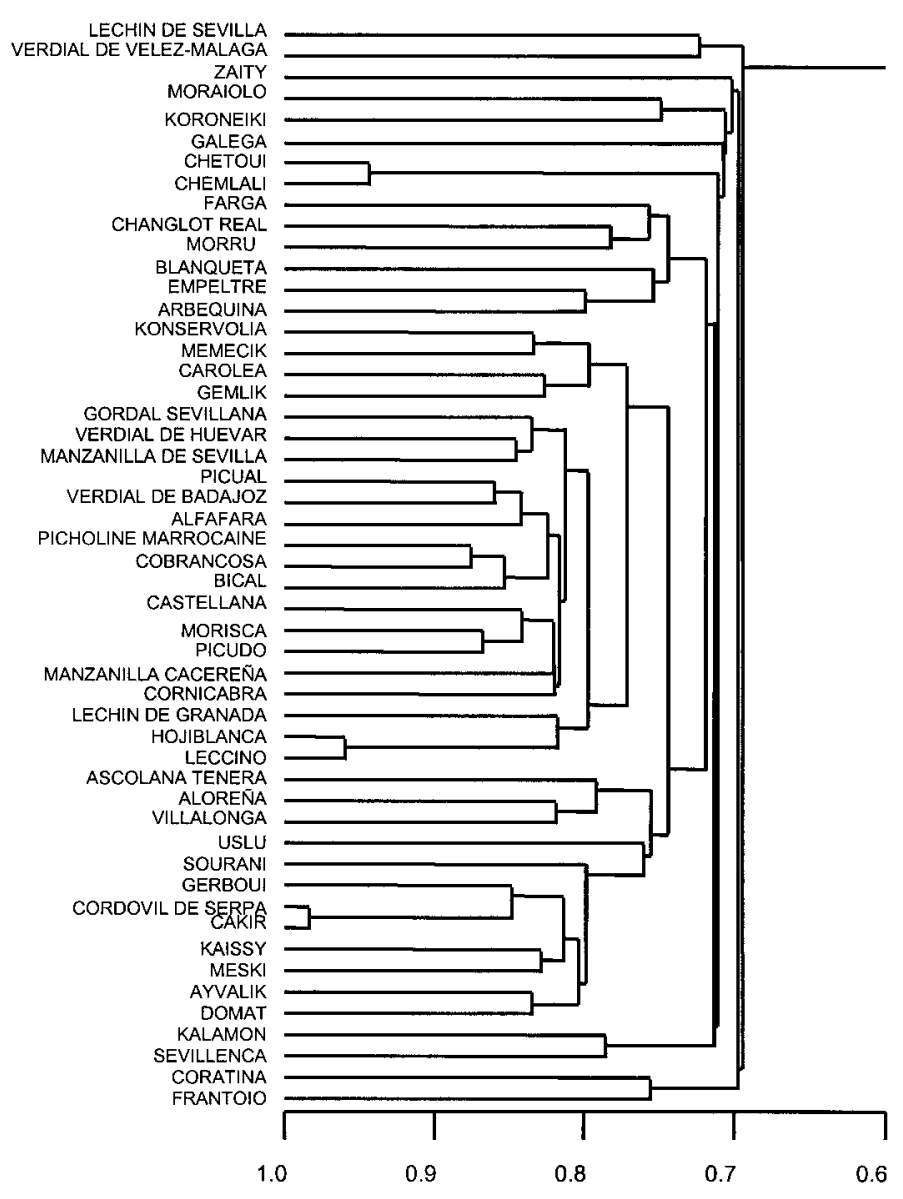

Fig. 3. An UPGMA dendogram based on the Jaccard similarity index among 51 olive cultivars for 190 RAPD fragments.

The selected primers yielded 247 banding patterns ( 5.4 per primer). The number of banding patterns per primer ranged from 2 (OPK-08, OPZ-19) to 15 (OPK-16). Relative frequency of the banding patterns varied from 0.02 to 0.88 . Average frequency of the banding patterns was low (0.2). Forty six unique banding patterns were found. These resulted either from the unique RAPD markers or from different combinations of polymorphic bands found (Tables 3 and 4).

CUlTIVAR IDENTIFICATION WITH RAPD-AGE MARKERS. The variability found allowed identification of the cultivars in various independent ways: a) unique RAPD markers, b) unique banding patterns, and c) combination of the banding patterns provided by different primers.

The presence of nine unique RAPD markers made identification of seven cultivars possible (Table 3 ), while 25 cultivars were identified by means of 46 unique banding patterns (Table 4). Most of the cultivars identified by unique markers and unique banding patterns correspond to those most important economically in the Mediterranean region. This is very important for identification of nursery plants. These cultivars included: 'Koroneiki' (Greece); 'Frantoio', 'Coratina' and 'Ascolana Tenera' (Italy); 'Picholine Marocaine' (Morocco); 'Cobrançosa' (Portugal); 'Arbequina', 'Empeltre', 'Farga' and 'Lechín de Sevilla' (Spain); 'Sourani' and 'Zaity' (Syria); 'Gerboui' (Tunisia); and 'Gemlik' and 'Uslu' (Turkey).

Establishment of a minimum number of primers with great capacity of discrimination made identification of all the cultivars possible. The combination of four primers OPA-01, OPK-08, OPX-01, and OPX-03 (Table 1, Figs. 1 and 2), which provided a high number of banding patterns accompanied sometimes by the presence of a multi-banding pattern, allowed identification of all the cultivars included in the study. Furthermore, the combination of eight additional primers (OPA-10, OPC-11, OPC-15, OPD-01, OPD-03, OPD-05, OPE-02, and OPK-14) which, in general, produced a smaller banding pattern (See Table 2) proved to be another way for identification of all the genotypes. Other combinations of primers could provide other possibilities for identification of the cultivars. The homonyms considered in this study: 'Lechín de Granada' and 'Lechín de Sevilla'; 'Manzanilla Cacereña' and 'Manzanilla de Sevilla'; 'Verdial de Badajoz', 'Verdial de Huevar' and 'Verdial de Vélez-Málaga', could be discriminated clearly and independently by only one or two primers.

GENETIC RELATIONSHIPS AMONG OLIVE CULTIVARS. In the dendrogram constructed by UPGMA cluster analysis (Fig. 3), similarity coefficients between all possible pairs of genotypes ranged from 0.71 to 0.96 . From this dendogram, most of the cultivars could be classified into three major groups.

Group 1 consisted of the cultivars 'Farga', 'Changlot Real', 'Morrut' 'Blanqueta', 'Empeltre', and 'Arbequina'. Those cultivars come from the regions of Catalonia, Valencia and Aragón, which are situated in eastern and northeast Spain.

Group 2 was composed of two branches; one of them comprised one Greek ('Konservolia'), one Italian ('Carolea'), and two Turkish ('Memecik' and 'Gemlik') cultivars; the other branch included most of the cultivars from central and southern Spain ('Gordal Sevillana', 'Verdial de Huevar', 'Manzanilla de Sevilla', 'Picual', 'Verdial de Badajoz', 'Alfafara', 'Bical', 'Castellana', 'Morisca', 'Picudo', 'Manzanilla Cacereña', 'Cornicabra', 'Lechín de Granada' and 'Hojiblanca') and some others from Morocco ('Picholine Marocaine'), Portugal ('Cobrançosa'), and Italy ('Leccino').

Group 3 included fourTurkish cultivars, 'Uslu', 'Çakir' 'Ayvalik', and 'Domat' from the six Turkish ones included in the study, two cultivars from Syria, 'Sourani' and 'Kaissy', two Tunisian cultivars, 'Gerboui' and 'Meski', and the Portuguese cultivar 'Cordovil de Serpa'. The subgroup formed by the cultivars 'Ascolana Tenera', 'Aloreña', and 'Villalonga' was added to this group. The cultivars 'Chetoui' and 'Chemlali', both from Tunisia, showed a high level of similarity (0.9) as did the Turkish cultivar 'Çakir' and the Portuguese one 'Cordovil de Serpa' (0.96).

Several pairs of cultivars branched in the dendrogram at low values of similarity $(0.72$ to 0.78$)$, i.e, they represent some small groups relatively unrelated to the main groups. This was the case for: 'Lechín de Sevilla' and 'Verdial de Vélez Málaga', both from Spain; 'Moraiolo' (Italy) and 'Koroneiki' (Greece); 'Kalamon' (Greece) and 'Sevillenca' (Spain); and 'Coratina' and 'Frantoio', both from Italy. Two cultivars, 'Zaity' (Syria) and 'Galega' (Portugal), were added to the dendrogram at low values of similarity. RAPD analysis indicated evidence of relationship for most of the cultivars, according to their geographic origin.

POLYMORPHISM LEVEL AND RESOLVING CAPACITY OF POLYACRYLAMIDE VERSUS AGAROSE. Although the rate of migration of RAPD amplification products in agarose and polyacrylamide gels was different, some similarities of RAPD profiles in both systems were found (Figs. 2c and 4). As expected, PAGE showed bands that were better-separated and more defined than AGE for all the primers tested except OPX-1, as indicated for OPX-3 (Figs. 2c and 4). This improved resolution capacity of PAGE resulted in the appearance of new scorable bands (Table 5).

The increase in polymorphism led to a greater discrimination 


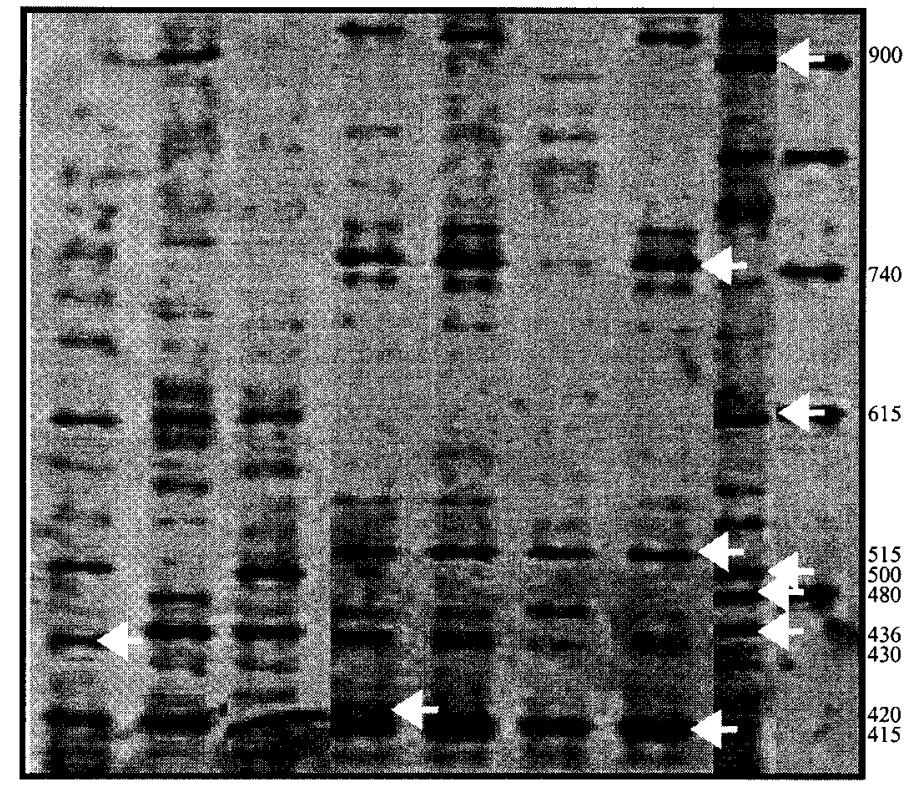

Fig. 4. RAPD amplification products obtained with the primer OPX-03 separated with PAGE. The selected amplification fragments are indicated with arrows. The first lane in the gel (on the right side) corresponds to the molecular marker. Molecular weights (bp) of the selected amplifications are also indicated on the right side of the figure.

capacity of the primers with PAGE than with AGE. Forty-four cultivars of the 46 studied with PAGE could be identified with the combination of just two primers, OPZ-19 and OPX-03, while with AGE, only six cultivars were identified by the same combination of primers.

The possibility of obtaining unique markers also increased with use of polyacrilamide. The primer OPX-03 produced a total of 21 unique banding patterns in polyacrylamide and only four in agarose. Thirteen of these unique banding patterns correspond to some of the most important Spanish cultivars: 'Alfafara', 'Arbequina', 'Blanqueta', 'Cornicabra', 'Empeltre', 'Farga', 'Gordal Sevillana', 'Lechín de Sevilla', 'Manzanilla de Sevilla', 'Morrut', 'Picual', 'Sevillenca', and 'Verdial de Huevar'.

\section{Discussion}

Olive PCR amplification products separated by AGE are characterized by their low molecular weight (Fabbri et al., 1995; Trujillo et al., 1999) and their distribution in a zone in the gel which does not lead to very high resolution. This limits their use for identification. A conservative criterion of band selection was adopted in this study. Therefore, a considerable amount of information had to be disregarded. Polyacrilamide gels provide a higher resolution of the lower molecular weight bands However,

Table 5. Comparison of the number of polymorphic bands obtained with polyacrylamide and agarose in 46 cultivars with four primers.

\begin{tabular}{lcc}
\hline \hline Primers & Polyacrylamide & Agarose \\
\hline OPE-02 & 9 & 3 \\
OPX-01 & 5 & 5 \\
OPX-03 & 10 & 5 \\
OPZ-19 & 4 & 1 \\
Total & 28 & 14 \\
\hline
\end{tabular}

preparation of polyacrylamide gels is more laborious and expensive than agarose gels.

The high level of polymorphism observed agrees with results of previous studies carried out in olive with RAPD markers (Bogani et al., 1994, Fabbri et al., 1995; Weismann et al., 1998). High levels of polymorphism in olive were also observed with isoenzymes (Pontikis et al., 1980; Trujillo et al., 1995), as well as with morphological descriptors (Barranco and Rallo, 1984; Cimato et al., 1993; Leitão, 1988; Prevost et al., 1993; Tous and Romero, 1993). This high degree of variability could be explained by the large diversity of olive cultivars (Bartolini et al., 1998; Lavee, 1994; Zohary and Spiegel-Roy, 1975) and the complexity of the olive genome; i.e., the olive has 23 pairs of chromosomes and is believed to have been originated by allopolyploidy (Zohary and Spiegel-Roy, 1975).

Identification of the cultivars in three independent ways, a) unique RAPD markers, b) unique banding patterns, and c) different combinations of the banding patterns provided by different primers, is clear evidence of the high discrimination capacity of these markers. This capacity is particularly useful for management of a germplasm bank, as it provides an inexpensive and reliable method for identification of a large number of cultivars. Many of the olive oil producing countries may not be able to afford use of expensive technology (like AFLP) for identification of native olive cultivars. The RAPD methodology offers a useful alternative. On the other hand, identification of some of the most important Mediterranean olive cultivars by cultivar-specific RAPD markers and banding patterns, provides the nursery industry with a useful tool to certify their plant material.

Discrimination of homonyms by just one or two primers demonstrates the presence of genetic differences between them. The homonyms have usually been troublesome in cultivar identification as names traditionally reflect common morphological traits (particularly of the fruit), place of origin or practical utility of the cultivars. Our results agree with previous morphological studies (Barranco and Rallo, 1984; Barranco, 1997) which demonstrated that generic names such as Lechín, Manzanilla, and Verdial include different cultivars. The capacity of RAPD markers to discriminate among olive homonyms is indicated in other studies (Mekuria et al., 1999; Wiesman et al., 1998).

The higher level of similarity observed among the cultivars originating from the same or nearby geographic origins agrees with both the hypothesis of authoctonal origin as well as the limited diffusion of olive cultivars from their zones of cultivation (Barranco, 1994; 1997; Rallo and Cidraes, 1978). Contrary to other studies with enzymes (Loukas and Krimbas, 1983) and RAPD markers (Fabbri et al, 1995) we did not find any relationships between olive cultivars and their fruit size.

In summary, RAPD markers provide highly discriminating and reliable DNA markers for management of olive germplasm banks. Identification of olive cultivars in germplasm banks will be possible with few combinations of carefully selected primers and results herein demonstrate that RAPD technique can be useful in classification. Moreover, the high number of unique markers observed in this study represents a very useful tool for certification of plant material in the nursery industry as true-totype, for paternity tests, and in future, for genetic mapping.

\section{Literature Cited}

Barranco,D. 1994. Estructura varietal del olivo en España. Agricultura 63:731-732. Barranco, D. 1997. Variedades y patrones, p. 59-80. In: D. Barranco, R. FernándezEscobar, and L. Rallo (eds.). El cultivo del olivo. Mundiprensa y Junta de 
Andalucía, Madrid, Spain.

Barranco, D. and L. Rallo. 1984. Las variedades de olivo cultivadas en Andalucía. M. ${ }^{\circ}$ de Agricultura, Junta de Andalucía, Madrid, Spain.

Bartolini, G., G. Prevost, C. Messeri, and G. Carignani. 1998. Olive germplasm: Cultivars and world-wide collections. Food and Agr. Org. Rome.

Bartolozzi, F., M.C. Warbuton, S. Arulsekar, and T.M. Gradziel. 1998. Genetic characterization and relatedness among California almond cultivars and breeding lines detected by randomly amplified polymorphic DNA (RAPD) analysis. J. Amer. Soc. Hort. Sci. 123:381-387.

Bassam, B.J., G. Caetano-Anollés, and P.M Gresshoff. 1991a. High-resolution DNA amplification fingerprinting (DAF): Detection of amplification fragment length polymorphisms in soybean using very short arbitrary oligonucleotide primers. Soybean Genet. Nswl. 18:279-283.

Bassam, B.J., G. Caetano-Anollés, and P.M. Gresshoff. 1991b. Fast and sensitive silver staining of DNA in polyacrylamide gels. Anal. Biochem. 80:81-84.

Bogani, P., D. Cavalieri, R. Petruccelli, L. Polsinelli, and G. Roselli. 1994 Identification of olive tree cultivars by using random amplified polymorphic DNA. Acta Hort. 356:98-101.

Caetano-Anollés, G. and B.J. Bassam. 1997. The origin of bermudagrass (Cynodon) off types inferred by DNA amplification fingerprinting. Crop Sci. 37:81-87.

Caetano-Anollés, G. B.J. Bassam, and P.M. Gresshoff. 1991. High-resolution DNA amplification fingerprinting (DAF): Detection of amplification fragment length polymorphisms in soybean using very short arbitrary oligonucleotide primers. Soybean Genet. Nswl. 18:279-283.

Cimato, A., C. Cantini, G. Sani, and M. Marranci. 1993. Il germoplasma dell'Olivo in Toscana. Ed. Regione Toscana, Florence, Italy.

del Río, C. and J.M. Caballero. 1994. Preliminary agronomical characterization of 131 cultivars introduced in the Olive Germplasm Bank of Cordoba in March 1987. Acta Hort. 356:110-115.

Deng, Z.N., A. Gentile, E. Nicolosi, F. Domina, A. Vardi, and E. Tribulato. 1995. Identification of in vivo and in vitro lemon mutants by RAPD markers. J. Hort. Sci. 70:117-125.

Fabbri, A., J.I. Hormaza, and V.S. Polito. 1995. Random amplified polymorphic DNA analysis of olive (Olea europaea L.) cultivars. J. Amer. Soc. Hort. Sci. 120:538-542.

Filippis, L.D., E. Hoffmann, R. Hampp, andF.L. De. 1996. Identification of somatic hybrids of tobacco generated by electrofusion and culture of protoplasts using RAPD-PCR. Plant Sci. Limerick 121:39-46.

Galderisi, U., M. Cipollaro, C. Dibernardo, L. Demasi, G. Galano, and A. Cascino. 1998. Molecular typing of Italian sweet chestnut cultivars by random amplified polymorphic DNA analysis. J. Hort. Sci. Biotechnol. 73:259-263.

Gerlach, H.K. and R. Stosser. 1997. Patterns of random amplified polymorphic DNAs for sweet cherry (Prunus Avium L.) cultivar identification. J. Appl. Bot.Angewandte. Bot. 71:212-218.

Gogorcena, Y. and D.E. Parfitt. 1994. Evaluation of RAPD marker consistency for detection of polymorphism in apricot. Sci. Hort. 59:163-167.

Harada, T., K. Matsukawa, T. Sato, R. Ishikawa, M. Niizeki, and K. Saito. 1993. DNA-RAPDs detect genetic variation and paternity in Malus. Euphytica 65:8791.

Hormaza, J.I., C. Dollo, and V.S. Polito. 1994. Determination of relatedness and geographical movements of Pistacia vera (pistachio, Anacardiaceae) germplasm by RAPD analysis. Econ. Bot. 48:344-358.

Hormaza, J.I., K. Pinney, and V.S. Polito. 1998. Genetic diversity of pistachio (Pistacia vera L.) germplasm based on randomly amplified polymorphic DNA (RAPD) markers. Econ. Bot. 52:78-87.

Jaccard, P. 1908. Nouvelle recherches sur la distribution florale. Bul. Soc. Vaud. Sci. Nat. 44:223-270.

Landry, B.S., R.Q. Li, W.Y. Cheung, and R.L. Granger. 1994. Phylogeny analysis of 25 apple rootstocks using RAPD markers and tactical gene tagging. Theor. Appl. Genet. 89:847-852.

Lavee, S. 1994. ¿Porqué la necesidad de nuevas variedades de olivos?, p. 29-37. In: Olivicultura. Fundación La Caixa-Agrolatino, Barcelona, Spain.

Leitão, F. 1988. Contributo para o conhecimiento de cultivares de (Olea Europaea L) quer sobre o aspecto de caracterizaçao, quer da productividade, determinante do seu valor económico. INIA. Estaçao Agronómica Nacional, Oeiras, Portugal. Lopez-Valenzuela, J.A., O. Martinez, and O. Paredes-Lopez. 1997. Geographic differentiation and embryo type identification in Mangifera indica L. HortScience 32:1105-1108.

Loukas, M. and C. B. Krimbas. 1983. History of olive cultivars based on their genetic distances. J. Hort. Sci. 58:121-127.

Lu, Z.-X., G.L. Reighard, W.V. Baird, A.G. Abbott, and S. Rajapakse. 1996. Identification of peach rootstock cultivars by RAPD markers. HortScience 31:127-129.

Machado, M.A., F.H. Coletta, M.N. Targon, and J.J. Pompeu. 1996. Genetic relationship of Mediterranean mandarins (Citrus deliciosa Tenore) using RAPD markers. Euphytica 92:321-326.

Mekuria, G.T., G.G. Collins, and M. Sedgley. 1999. Genetic variability between different accessions of some common commercial olive cultivars. J. Hort. Sci. Biotechnol. 74:309-314.

Murray, M.G. and W.F. Thompson. 1980. Rapid isolation on high molecular weight plant DNA. Nucleic Acids Res. 8:4321-4325.

Nicese, F.P., J.I. Hormaza, and C.H. McGranaham. 1998. Molecular characterization and genetic relatedness among walnut (Juglans regia L.) genotypes based on RAPD markers. Euphytica 101:199-206.

Ortiz, A., R. Renaud, I. Calzada, and E. Ritter. 1997. Analysis of plum cultivars with RAPD markers. J. Hort. Sci. 72: 1-9.

Ouazzani, N., R. Lumaret, P. Villemur, and di F. Guisto. 1993. Leaf allozyme variation in cultivated and wild olive trees (Olea europaea L.). J. Hered. 84:34-42.

Patumi, M., G. Fontanazza, R. Nucci, and C. Vaccaro. 1994. Preliminary studies on isoenzymatic and enzymatic activities isolated from olive plant. Acta Hort. 356:95-97.

Pontikis, C.A., M. Loukas, and G. Kousounis. 1980. The use of biochemical markers to distinguish olive cultivars. J. Hort. Sci. 55:333-343.

Prevost, G., G. Bartolini, and C. Messeri. 1993. Italian olive cultivars and their synonyms. Menegazzo edition. Lucca. Italy.

Rallo, L. and F. Cidraes. 1978. Mejora vegetal del olivo. II Seminario Oleícola Internacional. Ministerio de Agricultura, Madrid, Spain. p. 26-43.

Ronning, C.M., R.J. Schnell, and D.N. Kuhn. 1995. Inheritance of random amplified polymorphic DNA (RAPD) in Theobroma cacao L. J. Amer. Soc. Hort. Sci. 120:681-686.

Sambrook, J., E.F. Fritsch, and T. Maniatis. 1989. Molecular cloning: A laboratory manual. Cold Spring Harbor Lab. Press, Cold Spring Harbor, N.Y.

Tous, J. and A. Romero. 1993. Variedades del Olivo. Fundación "La Caixa", Barcelona, Spain.

Trujillo, I., R. de la Rosa, L. Rallo, and A. Belaj. 1999. Selection of RAPD markers for olive (Olea europaea L.) cultivar identification. In: I.T. Metzidakis and D.G.Voyiatzis. (eds.). Proc. 3rd Intl. ISHS Symp. on Olive Growing. Acta Hort 475:495-498.

Trujillo, I., L. Rallo, and P. Arus. 1995. Identifying olive cultivars by isozyme analysis. J. Amer. Soc. Hort. Sci. 120:318-324.

Vergari, G., M. Patumi, and G. Fontanazza. 1996. Use of RAPD markers in the characterisation of olive germplasm. Olivae 60:19-22.

Warburton, M.L. and F.A. Bliss. 1996. Genetic diversity in peach (Prunus persica L. Batch) revealed by randomly amplified polymorphic DNA (RAPD) markers and compared to inbreeding coefficients. J. Amer. Soc. Hort. Sci. 121:1012-1019.

Weeden, N.F., G.M. Timmerman, M. Hemmat, B.E. Kneen, and B.A. Lodhi. 1992. Inheritance and reliability of RAPD markers. Application of RAPD technology to plant breeding, p. 12-17. Crop. Sci. Soc. Amer, Madison. Wis.

Welsh, J. and M. McClelland. 1990. Fingerprinting genomes using PCR with arbitrary primers. Nucleic Acids Res. 18:7213-7218.

Wiesman, Z., N. Avidan, S. Lavee, and B. Quebedeaux. 1998. Molecular characterization of common olive varieties in Israel and the West bank using randomly amplified polymorphic DNA(RAPD) markers. J. Amer. Soc. Hort. Sci. 123:837841.

Williams, J.K., A.R. Kubelik, K.J. Livak, J.A. Rafalski, and S.V. Tingey. 1990. DNA polymorphisms amplified by arbitrary primers are useful as genetic markers. Nucleic Acids Res. 18:6531-6535.

Williams, J.K., A.R. Kubelik, J.A. Rafalski, and S.V. Tingey. 1991. Genetic analysis with RAPD markers, p. 431-439. In: J.W. Bennett and L.L. Lazur (eds) More gene manipulation in Fungi. Academic Press, New York.

Zohary, D. and P. Spiegel-Roy. 1975. Beginning of fruit growing in the old world. Science, 187:319-327. 